$\gamma$-globulin concentration of about $2 \times 10^{-2} \mu \mathrm{gm} . / \mathrm{ml}$., or an absolute equivalent of $2 \times 10^{-5} \mu \mathrm{gm}$. of $\gamma$-globulin detected on the test strip. This should make the test most suitable for the forensic laboratory for determining the nature and origin of minute quantities of antigenic substances.

Though the use of serum-impregnated membranes is alone described in this communication, $I$ have used a reversed form of the test by impregnating the strip with antigen and using it for the detection of antibody. In either case, speed of reaction and extreme economy of reactants are outstanding properties of the test.

I thank A. W. Wheeler for technical assistance.

Bencard Allergy Research Unit, Joseph G. FeinberG

Beecham Research Laboratories, Ltd., Betchworth, Surrey.

${ }^{1}$ Feinberg, J. G., Nature, 192, 985 (1961).

Kohn, J., Nature, 183, 1512 (1959).

\section{Enhancement of the Complement Fixation Reaction with a Soluble Antigen from Mycoplasma mycoides}

THE soluble polysaccharide (galactan) ${ }^{1}$ isolated from Mycoplasma mycoides var. mycoides (M. mycoides) can be used in precipitin or indirect hæmagglutination reactions to detect antibody to $M$. mycoides. When the galactan was used in place of the standard particulate antigen in the complementfixation test for contagious bovine pleuropneumonia ${ }^{2}$ with known positive sera, fixation of complement was usually weak or absent. As unheated normal bovine serum has been shown to potentiate complementfixation with heated bovine $e^{3,4}$ and swine ${ }^{5}$ antisera, its effect on complement-fixation by the galactanbovine antibody system was tested.

Normal bovine sera free from demonstrable bactericidal and complement-fixation antibody to $M$. mycoides were obtained from 4-6-month-old calves, and were used when fresh or within 3 weeks when stored at $-12^{\circ} \mathrm{C}$. Bovine antisera of known titre to the standard complement-fixation test ${ }^{2}$ and the hæmolytic system of the standard test were used. Dilutions were made in veronal buffer ${ }^{6}$.

Constant antigen and antiserum concentrations were tested with and without added normal bovine serum in the presence of dilutions of complement. To $0.4 \mathrm{ml}$. of a $1 / 40$ dilution of the test serum was added $0.5 \mathrm{ml}$. of each complement dilution and $0.2 \mathrm{ml}$. of a $1 / 40$ dilution of normal bovine serum, then $0.2 \mathrm{ml}$. galactan solution $(6 \mu \mathrm{gm} . / \mathrm{ml}$.) was added and the mixture was allowed to stand at $3-4^{\circ} \mathrm{C}$. overnight. In control tubes reagents omitted were replaced by buffer. In the morning the tubes were warmed to $37^{\circ} \mathrm{C} ., 0.2 \mathrm{ml}$. of hæmolytic system was added, and the test was read after incubation at $37^{\circ} \mathrm{C}$. for $30 \mathrm{~min}$. Fixation of complement did not occur when galactan and antibody were mixed unless unheated normal bovine serum was present (Table 1).

Table 1. EFfect of NORMal Bovine SERUM ON CoMplementFidion by Galactan ANTISERUM TO $M$. mycoides

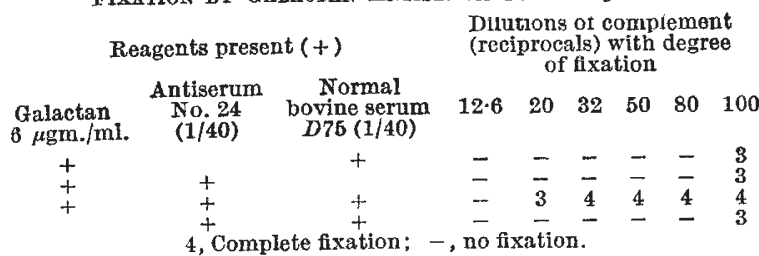

When either the antigen or antiserum concentration was varied independently in the presence of constant concentrations of complement and normal bovine serum, the optimal concentration of antigen was in the range of 6-12 $\mathrm{\mu gm}$. $/ \mathrm{ml}$. Antisera tested with galactan at this concentration gave lower titres than when tested with tho standard particulato antigen.

Four of five sera obtained from calves aged betweon 4 and 6 months potentiated complement-fixation with galactan and antiserum to $M$. mycoides.

The complement-fixation potentiating effect of normal bovine serum was found to be destroyed by heating to $56^{\circ} \mathrm{C}$. for $30 \mathrm{~min}^{3}$. Further work on the nature of the serum factor(s) is proceeding.

Division of Animal Health, G. S. Cotrew

Animal Health Research Laboratory, Commonwealth Scientific and Industrial Research Organization,

Parkville, N.2, Vietoria, Australia.

${ }^{1}$ Buttery, S. H., and Plackett, P., J. Gen. Microbiol., 23, 357 (1960). 2 Campbell, A. D., and Turner, A. W., A Astral. Vet. J., 29, 154 (1953). ${ }^{3}$ Nakamura, J., J. Jap. Soc. Vet. Sci., 15, 25 (1936).

Knight, G. J., and Cowan, R., J. Immunol., 86, 354 (1961).

- Boulanger, P., and Bannister, G. I., J. Immunol., 85, 368 (1960). ${ }^{8}$ Cohen, H. H., van Linge, B., de Boer, J. H., and Polman, H.,
Leeuwenhoek. Ned. Tijdschr., 19, 197 (1953).

\section{BIOLOGY}

\section{Factors affecting the Human Sex Ratio}

WE present here evidence suggesting the existence of at least two kinds of factors affecting the human sex ratio. As the sex ratio we use the number of male births per 100 female births. The evidence is based on family data collected by Geissler ${ }^{1}$ in 1889 and by ourselves ${ }^{2,3}$.

In Table 1 the sex ratio among the $N$ th children in the two series of families is given as a function of the number of boys $(N-1, N-2, \ldots$ or 0$)$ preceding this child. From these data two rules emerge: (1) Children of a certain parity tend to be boys if all the preceding children of the family have been boys, and they tend to be girls if all the preceding children have been girls. (2) If the 'unisexual' families exhibiting the above tendency (the highest and lowest figure in each column of Table 1) are excluded, it will be found that the sex ratio is the lower, the greater is the number of preceding male pregnancies. For this comparison, families with four or more children can be used (the encircled areas in Table 1). The only column which does not follow this rule is that of the fifth children of our series, and in this column the sex ratios are based on small numbers of families tested. From Table 2 it can be seen that in Geissler's series of families the downward trend of the sex ratio with the growing number of preceding boys is statistically significant. In our own series there is an identical 5 per cent decrease in the four-child families, but owing to the smaller number of families tested it is not statistically significant.

Table 3 shows that after one boy and two girls the sex ratio of the fourth child is high and after two boys and one girl it is low regardless of the order of birth of the preceding children. Thus the excess of boys or girls is not due to a switch of some families from a gynecophilic to an androphilic period or vice versa, an event postulated by Schützenberg ${ }^{4}$.

The data can be explained by postulating that, among other factors, there are the following two 